\title{
Parametric and Non-Parametric Methods for Efficiency Assessment of State Higher Vocational Schools in 2009-2011
}

\author{
Lesław Rządziński, Anna Sworowska
}

\begin{abstract}
A B S T R A C T
Objective: As a great number of higher schools in Poland are financed from public resources, there arises a question about the adequacy of those schools' inputs to the obtained outputs. The aim of this paper is to examine the technical efficiency of 27 state higher vocational schools in Poland.

Research Design \& Methods: The research was conducted for the years 2009-2011. The Stochastic Frontier Approach (SFA), as well as Data Envelopment Analysis (DEA) were applied. The other one was calculated both for Constant Returns to Scale (CRS) and for Variable Returns to Scale (VRS).
\end{abstract}

Findings: The majority of the studied schools, found as inefficient in the analysis conducted with the DEA method with CRS models, are found to be efficient in VRS models, demonstrate relatively lower efficiency when calculated with the SFA method.

Implications \& Recommendations: For the efficiency evaluation of higher education institutions, models of VRS should be applied. It enables to identify the units that despite operating in a different scale are fully efficient. The size and the scale of operations may have a significant impact on the efficiency of activities conducted by higher education institutions.

Contribution \& Value Added: The work compares two methods (parametric and non parametric) for the evaluation of technical efficiency that are present in subject literature (SFA is less popular) but are rarely evaluated and compared for its applicability to the higher education sector.

\section{Article type: research paper}

Keywords: $\quad$ SFA; DEA; efficiency; higher education

JEL codes: $\quad$ 123, C14

Received: 30 June 2015

Revised: 12 February 2016

Accepted: 14 February 2016

\section{Suggested citation:}

Rządziński, L., \& Sworowska, A. (2016). Parametric and Non-Parametric Methods for Efficiency Assessment of State Higher Vocational Schools in 2009-2011. Entrepreneurial Business and Economics Review, 4(1), 95-112, DOI: http://dx.doi.org/10.15678/EBER.2016.040107 


\section{INTRODUCTION}

Higher education constitutes a fundamental element shaping the country's economic policy. Modern states realise that investments into human capital (education, research) significantly increase the innovativeness of a given country's economy.

In an effort to meet the needs of the labour market, under the Act on Higher Vocational Schools of 26 June 1997, State Higher Vocational Schools (SHVS) were created. The idea behind the establishment of SHVSs was to ensure quick and practical preparation of professionals to work in a dynamically developing economy. Moreover, the undertaking had a social objective - the schools were intended for young people from families of limited means, coming from small towns (predominantly county towns). The factor in favour of establishing the schools was the so-called higher educational boom, as well as the baby boom. At the same time, these schools were meant to act as competition to private schools that managed to achieve a perfect match of the offered fields of study and market needs.

The higher education institutions presented in this paper may find that the evaluation of the technical efficiency of SHVSs' operation can serve as an element of social control (the schools are beneficiaries of public funds), as well as a source of valuable information on the areas requiring improvement.

The objective of this paper is to examine the technical efficiency of SHVSs in Poland. Detailed objectives include the study of two didactic and one financial model and a comparison of the results obtained with parametric and non-parametric methods.

\section{LITERATURE REVIEW}

An analysis of the efficiency of enterprise operations is an instrument of assessing the operations of a given entity in relation to others. It aims to demonstrate to less efficient entities any existing gaps and deficits in their activity. It is also intended to identify the areas requiring improvement and modifications. Commonly applied methods of efficiency measurement are based on ratio, parametric and non-parametric approaches (Szymańska, 2010).

Ratio analysis for efficiency measurement is based on developing relations between indices describing a model (typically, these include financial ratios, e.g. liquidity, profitability, efficiency, and debt ratios, etc.). A parametric method examines the relationships between input and output factors on the basis of a production function, demonstrating how a maximum effect can be achieved for a given level of inputs. In turn, nonparametric method is based on linear programming.

Data Envelopment Analysis (DEA) was first proposed by Charnes, Cooper and Rhodes (1978). It relied on an efficiency concept formulated twenty years before by Farrell (1957), which defined technical efficiency as a relation between productivity of one unit to the productivity of a benchmark unit ${ }^{1}$. DEA is based on the definition of efficiency as a relation of weighted sum of inputs to weighted sum of outputs (1).

\footnotetext{
${ }^{1}$ In his work, Farrell determined that one of the objects is more productive than the other if it is able to achieve the same output with lower inputs or if with the same inputs it is able to achieve a better output.
} 


$$
E=\frac{\sum_{r=1}^{n} u_{r} y_{r}}{\sum_{i=1}^{m} v_{i} x_{i}}
$$

where:

$$
\begin{aligned}
& E \text { - efficiency; } \\
& y \text { - output; } \\
& x \text { - input; } \\
& u \text { - weight defining the significance of individual outputs; } \\
& v \text { - weight defining the significance of individual inputs; } \\
& \gamma \text { - number of outputs; } \\
& \text { i - number of inputs. }
\end{aligned}
$$

Charnes, Cooper and Rhodes (1978) applied mathematical programming to the estimation of technical efficiency measurements and developed a model known in the literature of the subject as CCR. This is not the only model of DEA analyses. In later years, Banker, Charnes and Cooper (1984) differentiated other models. They considered an approach that took into account the effects of scale:

- CRS model (Constant Return to Scale ${ }^{2}$ );

- VRS model (Variable Return to Scale ${ }^{3}$ );

- NIRS model (Non Increasing Return to Scale);

- NDRS model (Non Decreasing Return to Scale).

The models constructed in this paper take into account constant return to scale (CRS) and variable return to scale (VRS) in order to obtain more precise outputs (enabling a comparison of schools of various size and scale of operations). It requires the result of CRS analysis to take two factors into account - scale efficiency (SE) and the so-called pure technical efficiency (PTE). The occurrence of any differences between the results of technical efficiency of individual CRS and VRS analyses is evidence that a given organisation is characterised by an inefficient scale (cf. Świtłyk \& Pasewicz, 2010).

All the presented models can be output-oriented (demonstrating by how much outputs ought to increase, while maintaining the present level of inputs, in order for an entity to become efficient), input-oriented (defining what level of input decrease, with presently achieved outputs, would ensure efficiency to a given entity) or they can be non-oriented models.

Data Envelopment Analysis is fairly widely used to measure technical efficiency of operations in agriculture, health care, education, banking, insurance companies, etc. The analysed entities need to feature the same characteristics. Furthermore, a proper selection of variables is of great significance. The literature of the subject does not provide a universal "key" for matching input and output data. Cunha and Rocha (2012), when analysing higher education in Portugal, assumed total expenditure per student and academic staff per student as inputs, whereas the total number of graduate students awarded Ph.D. degrees and the total number of courses offered constituted their outputs. In the study conducted in Brazil by Figueriredo de Franca, Neiva de Figueriredo and Lapa (2010) inputs included: the total number of professors and Ph.D.-holding academic teachers, the total number of administrative staff and the number of courses offered. The total number of

\footnotetext{
${ }^{2}$ It also appears in literature as CCR model (abbreviation from its authors' initials - Charnes, Cooper, Rhodes). ${ }^{3}$ It also appears in literature as BCC model (abbreviation from its authors' initials - Banker, Charnes, Cooper).
} 
enrolled students, graduates, and candidates registered to take the entrance examination were chosen as output variables. In the study carried out by Koksal and Nalc (2006) in Turkey, the elements selected as inputs were academic staff salaries, the average number of publications per academic staff member, the weighted sum of students after the first, third and fifth year of study. The output variables included the weighted sum of graduates (of B.Sc., M.Sc. and Ph.D. studies) and an average grade. Johnes (2006) indicates the quantity and quality of undergraduates (calculated as the total number of full-time undergraduate students studying for the first degree multiplied by the average A level points for first year full-time undergraduate students), the quantity of postgraduates, expenditure on administration, and the value of interest payments and depreciation as significant inputs. As significant outputs in the English higher education production process she treats the quantity and quality of undergraduate degrees (the total number of first degrees awarded weighted by degree classification), the quantity of postgraduate degrees and research (the value of the recurrent grant for research awarded by the Higher Education Funding Council for England in British Pounds). On the other hand, to capture research output, Athanassopoulos and Shale (1997) used the national research performance index - the ratings of the Research Assessment Exercise in the UK. Leitner et al. (2007), while researching Austrian universities, adopted the total number of staff and department floor space as input variables. The outputs comprised of financial funds provided by third parties, overall finished projects per person, finished (ordered) projects of the department, the number of examinations, the number of finished, supervised diploma theses, the number of external reports, monographs, projects, patents, publications and the number of finished, supervised Ph.D. theses. The Australian case by Abbott and Doucouliagos (2003) focuses on inputs such as the total number of the academic staff, the number of non-academic staff (fulltime equivalent), expenditure on all other inputs other than labour inputs (including expenditure on energy, non-salary academic and administration services, buildings and grounds, libraries and student services), and the value of non-current assets. Those authors also used measures of teaching output (the number of equivalent full-time students, the number of post-graduate and under-graduate degrees enrolled, as well as the number of post-graduate degrees conferred and the number of under-graduate degrees conferred) and research output (Research Quantum Allocation that each Australian university receives on the base of the composite index calculated from a mix of the National Competitive Grants Index, public sector research funding, research and scholarly publications and higher degree research completions, and the number of competitive grants and industry funding received). Also Avkiran (2001) investigated the technical and scale efficiency of Australian universities using inputs and outputs within three performance models: overall performance, the performance of the delivery of educational services, and the performance of fee-paying enrolments. In Italy, Bergantino et al. (2012) limited inputs to the number of academics, and assumed the number of undergraduates, postgraduates and on-time graduations as outputs. While analysing German universities, Warning (2004) chose expenditure on personnel and other expenditure as her input variables. She recognized the number of publications and the number of personnel as outputs. However, Kempkes and Pohl (2010) for German academic institutions included an output measure for teaching, such as the number of students that have successfully completed their studies. During a study on Japanese universities, researchers Aoki et al. (2010) chose to use the 
number of staff, the number of faculties, education and research expenses, grant-in aid for management, general and administrative costs, and profit from donations as inputs. Their outputs are the number of papers, the number of graduate and undergraduate students, the number of library books, grants-in-aid for scientific research, contract research funds, as well as profit from business. In turn, Iraqi researchers, Monfared and Safi (2013) assumed the following as inputs in their model: the number of B.Sc. students, the number of M.Sc. and Ph.D. students, the number of fee-paying students, the evaluation of education quality (conducted by students), the grade earned on an entrance examination, the number of faculty members (instructors, assistant professors), the number of faculty members (associated professors, professors), the faculty members' positions (weighted average), the number of adjunct professors, the number of administrative staff, the faculty floor space, the value of laboratory equipment, budget per student, total incomes. The outcomes of their study included teaching load, the average grade, the employment rate of university graduates, the number of Master's degree theses meriting honours, the university position in the higher schools' ranking, the university completion rate, the number of publications (in journal papers, monographs, conference papers), the number of highly rated publications, the number of invitations to speaking engagements at international conferences, donations, grants and external contracts (research, consultancy), awards and recognition for education and research (at national and international level), the number of patents, the number of internationally renowned scientists, taxes and social contributions.

When analysing the global literature, it becomes noticeable that the selection of variables chiefly depends on the scope of data available to a researcher. Among Polish researchers of the subject of the higher education efficiency, this subject was undertaken by, inter alia, Świtłyk, who jointly with Mongiało (2013) assumed that input variables would include the number of staff members who are not academic teachers, the number of independent researchers, the number of assistant professors and instructors, the number of research and teaching staff members, the value of funds obtained for teaching, the value of funds obtained for research, the value of material and energy consumption, outsourcing, gross salaries, depreciation and other operating costs. Their outputs included the total number of students (full-time, extramural, doctoral, post-graduate students), as well as the value of funds obtained for research. In another paper, Świtłyk together with Pasewicz included the following as input variables: depreciation costs, the costs of material and energy consumption, the costs of outsourcing, salaries and benefits, the value of investment spending, the number of independent researchers, the number of assistant professors, the number of instructors, the total number of academic teachers, the number of scientific and technical staff members, the number of librarians, the number of administrative staff members. The number of undergraduates and graduates was selected as outcome variables. Nazarko et al. (2008) made a different selection of variables. They chose the value of teaching grants as inputs, and the level of student number factor, as well as the number of national and foreign grants. In another study, Nazarko and Saparauskas (2014) recognized government budget subsidies, the population size of the city in which a university is located, and the percentage of students with need-based financial aid as inputs. The outputs in the study included the weighted number of full-time students, the weighted number of full-time doctoral students, the employer hiring expectations with 
respect to graduates, and the parametric assessment of scholarly achievements. Yet another Polish researcher who studied efficiency in education was Wolszczak-Derlacz (2013). She assumed that input variables should include the share of public funds in the total income amount, the number of staff members employed at the position of ordinary and extraordinary professors in the total number of academic teachers, the number of doctoral students in relation to the number of academic teachers, the year of establishment, GDP per capita for a region (voivodeship) in which a higher education institution is located, a zero-one variable (1 awarded to technical schools of higher education), the number of various faculties, the number of full-time university employees. The output was the level of student number factor. In the paper Ćwiąkała-Małys (2010) adopts the number of academic teachers, the number of non-academic staff members, the size of the fixed property, teaching grant amounts, operating costs, costs except for the costs of work as inputs in the model. The total number of students and the number of university completing students constitute the outputs.

The parametric method of SFA is a less popular method of evaluating the efficiency of higher education. When analysing Polish and international literature, one finds it difficult to spot any researchers who used the method to evaluate university efficiency. Lampe and Hilgers (2015) made a comparison between the number of publications concerning the DEA and SFA methods. A total of 4,782 articles regarding these methods were published in scientific journals, of which 761 papers with respect to SFA and 4021 with respect to DEA (the data set comprised the years 1987-2011). Largely, those are publications on analysing the efficiency of health care, banking and agriculture.

The SFA method was devised by Aigner et al. (1977). It estimated efficient cost or production, taking into consideration a stochastic nature of input variables (2).

$$
y_{i}=\alpha+\beta x_{i}+\varepsilon_{i}
$$

where:

$y$ - either product or costs efficiency;

$i$ - number of observations;

$\alpha$ - constant;

$x$ - vector of explanatory variables;

$\beta$ - relations between an explained and explanatory variable;

$\varepsilon$ - (residual) deviation between two data obtained as a result of observation and the relations predicted by an explanatory variable of the model;

The SFA differs from other methods by its separation of measurement errors from the factor responsible for inefficiency, while at the same time taking into consideration stochastic disturbances.

\section{MATERIAL AND METHODS}

This study applied a parametric method of SFA and non-parametric method of DEA. For the DEA method, input- and output-oriented models with constant and variable returns to scale were developed. The outputs obtained from both of these methods were subsequently compared. The study concerned State Higher Vocational Schools and it covered the years 2009-2011. In Poland, 36 State Higher Vocational Schools operated in the period of 2009-2010. The study omitted the schools from Bielsko Biała (incomplete data), 
Gniezno, Głogów, Oświęcim, Sandomierz, Skierniewice, Wałcz, Zamość (no data), Koszalin (too short period of operation). Individual higher education institutions were assigned adequate $\mathrm{DMU}^{4}$ in line with Table 1.

Table 1. SHVS used in the research process

\begin{tabular}{|c|c|}
\hline DMU & Location \\
\hline DMU1 & Chełm \\
\hline DMU2 & Ciechanów \\
\hline DMU3 & Elbląg \\
\hline DMU4 & Gorzów Wielkopolski \\
\hline DMU5 & Jarosław \\
\hline DMU6 & Jelenia Góra \\
\hline DMU7 & Kalisz \\
\hline DMU8 & Konin \\
\hline DMU9 & Krosno \\
\hline DMU10 & Legnica \\
\hline DMU11 & Leszno \\
\hline DMU12 & Łomża \\
\hline DMU13 & Nowy Sącz \\
\hline DMU14 & Nowy Targ \\
\hline DMU15 & Nysa \\
\hline DMU16 & Opole \\
\hline DMU17 & Piła \\
\hline DMU18 & Płock \\
\hline DMU19 & Przemyśl \\
\hline DMU20 & Racibórz \\
\hline DMU21 & Sanok \\
\hline DMU22 & Sulechów \\
\hline DMU23 & Suwałki \\
\hline DMU24 & Tarnobrzeg \\
\hline DMU25 & Tarnów \\
\hline DMU26 & Wałbrzych \\
\hline DMU27 & Włocławek \\
\hline
\end{tabular}

Source: own elaboration based on MNiSW (The Ministry of Science and Higher Education) (2012, 2011, 2010).

The study used factual materials available in Monitor B and "Higher Education" guide. In each model the following inputs were used for the study: land $(x 1)$, buildings and civil engineering structures ( $\mathrm{x} 2$ ), plant and machinery $(\mathrm{x} 3)$, other fixed assets ( $\mathrm{x} 4)$, consumption of materials and energy $(x 5)$, outsourcing $(x 6)$, remuneration + social security and other benefits ( $x 7)$, other prime costs + taxes and charges ( $x 8)$. The assumed outcomes (depending on the model developed) were the total number of full-time and extramural students (y1), the total number of full-time and extramural graduates ( $y 2)$, or income from sales (y3). The following models were developed for the purpose of the study:

\footnotetext{
${ }^{4} \mathrm{DMU}$ (Decision Making Unit) defines a given organisational unit that is responsible for the conversion of specific inputs into desirable outputs. The basic principle of DMU selection is that they should feature the identical input and output structure.
} 
o for the non-parametric method of DEA:

a) didactic model_1, for which the number of students was assumed as an output:

- D_MOD_DID_S_C_I - input-oriented model with constant return to scale;

- D_MOD_DID_S_V_I - input-oriented model with variable return to scale;

- D_MOD_DID_S_C_O - output-oriented model with constant return to scale;

- D_MOD_DID_S_V_O - output-oriented model with variable return to scale;

b) didactic model _2, for which the number of alumni was assumed as an output:

- D_MOD_DID_A_C_I- input-oriented model with constant return to scale;

- D_MOD_DID_A_V_I - input-oriented model with variable return to scale;

- D_MOD_DID_A_C_O - output-oriented model with constant return to scale;

- D_MOD_DID_A_V_O - output-oriented model with variable return to scale;

C) financial model_3, for which income from sales was assumed as an output:

- D_MOD_FIN_C_I - input-oriented model with constant return to scale;

- D_MOD_FIN_V_I - input-oriented model with variable return to scale;

- D_MOD_FIN_C_O - output-oriented model with constant return to scale;

- D_MOD_FIN_V_O - output-oriented model with variable return to scale;

o for the parametric method of SFA:

a) didactic model_1 (S_MOD_DID_S), for which the number of students was assumed as an output;

b) didactic model_2 (S_MOD_DID_A), for which the number of alumni was assumed as an output;

c) financial model_3 (S_MOD_FIN), for which income from sales was assumed as an output.

The choice of variables for individual models and research methods is presented in Table 2.

Table 2. Input and output variables used in the research models

\begin{tabular}{|c|c|c|c|c|c|c|}
\hline \multirow{2}{*}{$\begin{array}{c}\text { Vari- } \\
\text { ables }\end{array}$} & \multicolumn{5}{|c|}{ DEA } & \multicolumn{3}{c|}{ SFA } \\
\cline { 2 - 7 } & $\begin{array}{c}\text { didactic } \\
\text { model_1 }\end{array}$ & $\begin{array}{c}\text { didactic } \\
\text { model_2 }\end{array}$ & $\begin{array}{c}\text { financial } \\
\text { model_3 }\end{array}$ & $\begin{array}{c}\text { didactic } \\
\text { model_1 }\end{array}$ & $\begin{array}{c}\text { didactic } \\
\text { model_2 }\end{array}$ & $\begin{array}{c}\text { financial } \\
\text { model_3 }\end{array}$ \\
\hline $\mathbf{x 1}$ & + & + & + & + & + & + \\
\hline $\mathbf{x 2}$ & + & + & + & + & + & + \\
\hline $\mathbf{x 3}$ & + & + & + & + & + & + \\
\hline $\mathbf{x 4}$ & + & + & + & + & + & + \\
\hline $\mathbf{x 5}$ & + & + & + & + & + & + \\
\hline $\mathbf{x 6}$ & + & + & + & + & + & + \\
\hline $\mathbf{x 7}$ & + & + & + & + & + & + \\
\hline $\mathbf{x 8}$ & + & + & + & + & + & + \\
\hline y1 & + & - & - & + & - & - \\
\hline y2 & - & + & - & - & + & - \\
\hline y3 & - & - & + & - & - & + \\
\hline
\end{tabular}

Source: own elaboration. 
Table 3. Statistical data of variables

\begin{tabular}{|c|c|c|c|c|c|c|c|c|c|c|c|c|}
\hline & \multicolumn{4}{|c|}{2009} & \multicolumn{4}{|c|}{2010} & \multicolumn{4}{|c|}{2011} \\
\hline & Mean & Minimum & Maximum & Std. dev. & Mean & Minimum & Maximum & Std. dev. & Mean & Minimum & Maximum & Std. dev. \\
\hline$x 1$ & 2213633 & 240109 & 8604597 & 2027972 & 2397917 & 467039 & 8604597 & 1956648 & 2504423 & 432497 & 8602111 & 1895020 \\
\hline$x 2$ & 21982145 & 4354198 & 80196024 & 14789726 & 23710263 & 3932298 & 76189693 & 14534700 & 30870728 & 4614724 & 74002618 & 16649500 \\
\hline x3 & 622232 & 93149 & 2542915 & 536139 & 722997 & 78060 & 2778023 & 663464 & 916306 & 187921 & 5254938 & 1012329 \\
\hline$x 4$ & 917696 & 127064 & 9317473 & 1741799 & 1069327 & 142226 & 11310834 & 2122135 & 986551 & 83490 & 8018545 & 1504348 \\
\hline$\times 5$ & 1108784 & 399753 & 2039043 & 419928 & 1263703 & 491912 & 2203498 & 459737 & 1376233 & 423139 & 3516348 & 640206 \\
\hline$x 6$ & 1238308 & 398369 & 3775227 & 767626 & 1267616 & 291112 & 3764943 & 741827 & 1305278 & 328043 & 4029860 & 889199 \\
\hline$x 7$ & 27553272 & 5641729 & 381060650 & 70867428 & 15022203 & 6301331 & 28562562 & 6089848 & 15655879 & 6934420 & 29079120 & 6243697 \\
\hline$x 8$ & 471685 & 46250 & 1032670 & 270317 & 688729 & 48398 & 1676391 & 430840 & 766561 & 30267 & 1984260 & 553805 \\
\hline y1 & 2979 & 1289 & 5787 & 1262 & 2872 & 1144 & 5537 & 1210 & 2698 & 1003 & 5004 & 1160 \\
\hline y2 & 818 & 279 & 1722 & 414 & 792 & 336 & 1574 & 337 & 780 & 312 & 1538 & 343 \\
\hline y3 & 15063128 & 1247807 & 31933503 & 8772199 & 17429620 & 1858436 & 35884020 & 8910644 & 17685518 & 2198060 & 35799103 & 9097670 \\
\hline
\end{tabular}




\section{RESULTS AND DISCUSSION}

\section{Efficiency of SHVS over the period 2009-2011}

Calculation results are given in Table 4, Table 5 and Table 6. In 2009, the average efficiency ratio of the analysed schools of higher education, according to didactic model_1, for inputand output-oriented CRS, was equal to $91.6 \%$, for input-oriented VRS it stood at $95.42 \%$, for output-oriented VRS it was $96.41 \%$, while for SFA - 99.09\%. In 2009, 16 efficient higher schools were recorded in accordance with the CRS approach (59.26\% of the analysed sample), 21 efficient schools of higher education were recorded for the VRS approach (77.78 $\%$ of the analysed sample). These differences indicate that the inefficiency demonstrated by some of the schools, with the assumption of the same effects of scale (DMU02, DMU12, DMU21, DMU22, DMU24), results solely from their operating in a different scale of activity. It means that despite the fact that those organisations are shown as inefficient in the CRS method, they achieve full efficiency when all the effects of scale are taken into account; therefore, in their case it is not necessary to decrease inputs in order to obtain an optimal number of students. In the case of the SFA method, 15 SHVSs were above average ( $55.56 \%$ of the analysed sample). In 2010, the average efficiency ratio for input- and output-oriented CRS was equal to $91.90 \%$, for input-oriented VRS it stood at $95.96 \%$, for output-oriented VRS it amounted to $96.14 \%$, while for SFA it was $74.97 \%$. In 2010, in line with the CRS approach, 13 efficient schools of higher education were recorded $(48.15 \%$ of the analysed sample), while in the VRS approach it was 19 efficient higher education institutions ( $70.37 \%$ of the analysed sample). In the SFA method 16 SHVSs were above average (59.26 \% of the analysed sample). In 2011, the average efficiency ratio in the didactic model_1 for input- and output-oriented CRS was equal to $95.47 \%$, for input-oriented VRS it was $98.86 \%$, for output-oriented VRS it stood at $97.76 \%$, while for SFA it amounted to $75.30 \%$. In 2011, 18 efficient higher education institutions were recorded in the CRS approach (66.67 \% of the analysed sample), while in the VRS approach there were 24 efficient higher education institutions ( $88.89 \%$ of the analysed sample). In the case of the SFA method, 16 SHVSs were above average (59.26 \% of the analysed sample).

For didactic model_2 in 2009, the average efficiency ratio for CRS was $92.03 \%$, for VRS it was $97.04 \%$, and for SFA it was $71 \%$. In 2009 in the CRS approach there were 19 efficient higher schools identified ( $70.37 \%$ of the analysed sample), in the VRS approach 23 efficient higher education institutions were recognized $(85.19 \%$ of the analysed sample). In the SFA method 13 SHVSs that reached the efficiency level over the average were recorded ( $48.15 \%$ of the analysed sample). In 2010, the average efficiency ratio in the CRS approach was $90.29 \%$, in the VRS input-oriented approach it was $95.58 \%$, in VRS outputoriented it was $94.24 \%$, and in SFA it was $69.68 \%$. In 2010 in the CRS approach 15 efficient higher education institutions were recognized ( $55.56 \%$ of the analysed sample), in the VRS approach 20 effective higher schools were identified ( $74.07 \%$ of the analysed sample). In the SFA method 16 SHVSs that reached the efficiency level over the average were recorded ( $59.26 \%$ of the analysed sample). In 2011, the average efficiency ratio for CRS was 88.15 $\%$, for the VRS input-oriented approach it was $93.37 \%$, for the VRS output-oriented approach it was $92.94 \%$, and for SFA it was $99.07 \%$. In 2011 in the CRS approach 13 efficient higher education institutions were recorded ( $48.15 \%$ of the analysed sample), in VRS - 17 efficient higher schools (62.96 \% of the analysed sample). In the SFA method 10 SHVSs 
Table 4. SHVSs' efficiency in didactic model_1 (output: number of students)

\begin{tabular}{|c|c|c|c|c|c|c|c|c|c|c|c|c|c|c|c|}
\hline \multirow[b]{2}{*}{$\sum_{0}^{?}$} & \multicolumn{5}{|c|}{2009} & \multicolumn{5}{|c|}{2010} & \multicolumn{5}{|c|}{2011} \\
\hline & 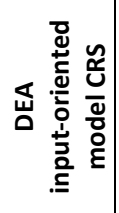 & 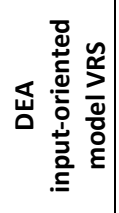 & 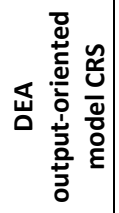 & 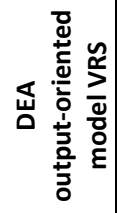 & 嵌 & 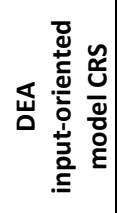 & 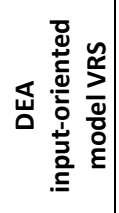 & 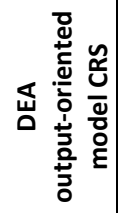 & 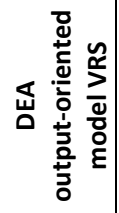 & 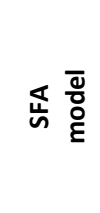 & 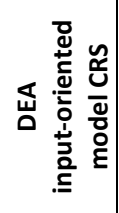 & 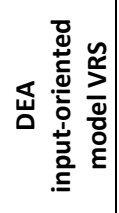 & 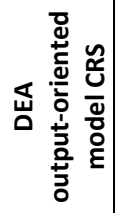 & 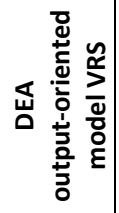 & 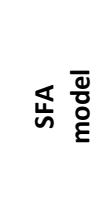 \\
\hline 01 & 0.62367 & 0.62522 & 0.62367 & 0.71029 & 0.99059 & 0.58741 & 0.59211 & 0.58741 & 0.68239 & 0.48188 & 0.73614 & 0.74056 & 0.73614 & 0.76702 & 0.48711 \\
\hline 02 & 0.91373 & 1.00000 & 0.91373 & 1.00000 & 0.99064 & 1.00000 & 1.00000 & 1.00000 & 1.00000 & 0.27328 & 1.00000 & 1.00000 & 0000 & .00000 & \\
\hline 03 & 1.00000 & 1.00000 & 1.00000 & 1.00000 & 0.99087 & 1.00000 & 1.00000 & 1.00000 & 1.00000 & 0.91895 & 1.00000 & 1.00000 & 1.00000 & 1.00000 & 0.75440 \\
\hline 04 & 0.71271 & 0.71330 & 0.71271 & 0.77591 & 0.99088 & 0.98379 & 1.00000 & 0.98379 & 1.00000 & 0.82378 & 1.00000 & 1.00000 & 1.00000 & 1.00000 & 0.99323 \\
\hline 05 & 1.00000 & 1.00000 & 1.00000 & 1.00000 & 99112 & .00000 & 1.00000 & 1.00000 & 1.00000 & 0.94570 & .87657 & 1.00000 & 7657 & 1.00000 & 0.99549 \\
\hline 06 & 0.88287 & 0.92107 & 0.88287 & 0.93485 & 0.99069 & 0.92976 & 0.93029 & 0.92976 & 0.96128 & 0.71982 & 0.87833 & 1.00000 & 0.87833 & 1.00000 & 0.37625 \\
\hline 07 & 0.66252 & 0.74577 & 0.66252 & 0.84363 & 0.99094 & 0.67121 & 0.91257 & 0.67121 & 0.97798 & 0.83590 & 0.83474 & 1.00000 & 0.83474 & 1.00000 & 0.80674 \\
\hline 08 & 1.00000 & 1.00000 & 1.00000 & 1.00000 & 99122 & .00000 & 1.00000 & 000 & 1.00000 & 991 & 00000 & 1.00000 & 000 & 000 & 896 \\
\hline 09 & 1.00000 & 1.00000 & 1.00000 & 1.00000 & 0.99123 & 0.98433 & 1.00000 & 3433 & 1.00000 & 0.99992 & 00000 & 1.00000 & 000 & 000 & 155 \\
\hline 10 & 1.00000 & 1.00000 & 1.00000 & 1.00000 & 0.99090 & 1.00000 & 1.00000 & 1.00000 & 1.00000 & 0.99993 & 1.00000 & 1.00000 & 1.00000 & 1.00000 & 0.80837 \\
\hline 11 & 0.99167 & 0.99556 & 0.99167 & 0.99605 & 0.99090 & 0.95747 & 0.95994 & 0.95747 & 0.95843 & 0.67517 & 1.00000 & 1.00000 & 1.00000 & 1.00000 & 0.87178 \\
\hline 12 & 0.86206 & 1.00000 & 0.86206 & 1.00000 & 0.99064 & 0.88865 & 0.97866 & 0.88865 & 0.91698 & 0.78681 & 1.00000 & 1.00000 & 1.00000 & 1.00000 & 0.47598 \\
\hline 13 & 1.00000 & 1.00000 & 1.00000 & 1.00000 & 0.99109 & 1.00000 & 1.00000 & 1.00000 & 1.00000 & 0.99986 & 1.00000 & 1.00000 & 1.00000 & 1.00000 & 0.99413 \\
\hline 14 & 1.00000 & 1.00000 & 1.00000 & 1.00000 & 0.99114 & 1.00000 & 1.00000 & 1.00000 & 1.00000 & 0.70512 & & 1.00000 & & 000 & 0.69226 \\
\hline 15 & 1.00000 & 1.00000 & 1.00000 & 1.00000 & 0.99095 & 1.00000 & 1.00000 & & 1.00000 & 0.86902 & & 1.00000 & & 1.00000 & 0.99195 \\
\hline 16 & 1.00000 & 1.00000 & 1.00000 & 1.00000 & 0.99047 & 1.00000 & 1.00000 & 1.00000 & 1.00000 & 0.39989 & 1.00000 & 1.00000 & 1.00000 & 1.00000 & 0.53639 \\
\hline 17 & 0.73968 & 0.76187 & 0.73968 & 0.76937 & 0.99083 & 0.67485 & 0.79397 & 0.67485 & 0.89708 & 0.99982 & 0.96270 & 0.98643 & 0.96270 & 0.98825 & 0.56258 \\
\hline 18 & 1.00000 & 1.00000 & 1.00000 & 1.00000 & 0.99091 & 0.96523 & 1.00000 & 0.96523 & 1.00000 & 0.93001 & 1.00000 & 1.00000 & 1.00000 & 1.00000 & 0.99660 \\
\hline 19 & 1.00000 & 1.00000 & 1.00000 & 1.00000 & 0.99068 & 0.91814 & 1.00000 & 0.91814 & 1.00000 & 0.36509 & 0.92558 & 1.00000 & 0.92558 & 1.00000 & 0.77708 \\
\hline 20 & 1.00000 & 1.00000 & 1.00000 & 1.00000 & 0.99095 & 1.00000 & 1.00000 & 1.00000 & 1.00000 & 0.99788 & 1.00000 & 1.00000 & 1.00000 & 1.00000 & 0.96386 \\
\hline 21 & 0.58493 & 1.00000 & 0.58493 & 1.00000 & 0.99048 & 0.82098 & 1.00000 & 0.82098 & 1.00000 & 0.48644 & 0.97053 & 1.00000 & 0.97053 & 1.00000 & 0.37839 \\
\hline 22 & 0.93420 & 1.00000 & 0.93420 & 1.00000 & 0.99082 & 0.74679 & 0.82145 & 0.74679 & 0.75260 & 0.52779 & 0.59374 & 0.96480 & 0.59374 & 0.64004 & 0.18424 \\
\hline 23 & 1.00000 & 1.00000 & 1.00000 & 1.00000 & 0.99064 & 0.80593 & 0.91702 & 0.80593 & 0.81090 & 0.61921 & 0.99982 & 1.00000 & 0.99982 & 1.00000 & 0.63492 \\
\hline 24 & 0.82587 & 1.00000 & 0.82587 & 1.00000 & 0.99067 & 0.87971 & 1.00000 & 0.87971 & 1.00000 & 0.49680 & 1.00000 & 1.00000 & 1.00000 & 1.00000 & 0.87959 \\
\hline 25 & 1.00000 & 1.00000 & 1.00000 & 1.00000 & 0.99103 & 1.00000 & 1.00000 & 1.00000 & 1.00000 & 0.99993 & 1.00000 & 1.00000 & 1.00000 & 1.00000 & 0.97238 \\
\hline 26 & 1.00000 & 1.00000 & 1.00000 & 1.00000 & 0.99096 & 1.00000 & 1.00000 & 1.00000 & 1.00000 & 0.91606 & 1.00000 & 1.00000 & 1.00000 & 1.00000 & 0.94461 \\
\hline 27 & 1.00000 & 1.00000 & 1.00000 & 1.00000 & 0.99076 & 1.00000 & 1.00000 & 1.00000 & 1.00000 & 0.46867 & 1.00000 & 1.00000 & 1.00000 & 1.00000 & 0.77883 \\
\hline
\end{tabular}

Source: own elaboration. 
Table 5. SHVSs' efficiency in didactic model_2 (output: number of alumni)

\begin{tabular}{|c|c|c|c|c|c|c|c|c|c|c|c|c|c|c|c|}
\hline \multirow[b]{2}{*}{$\sum_{0}^{2}$} & \multicolumn{5}{|c|}{2009} & \multicolumn{5}{|c|}{2010} & \multicolumn{5}{|c|}{2011} \\
\hline & 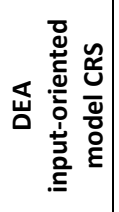 & 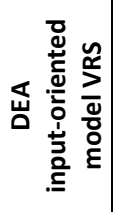 & 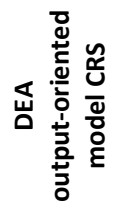 & 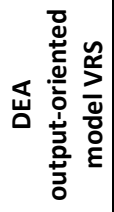 & 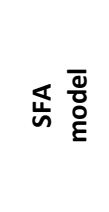 & 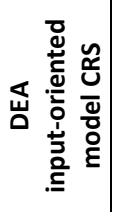 & 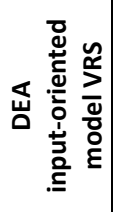 & 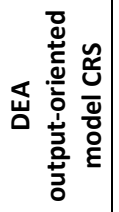 & 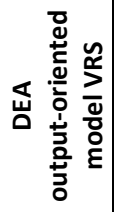 & 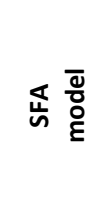 & 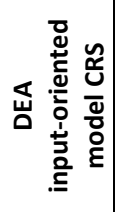 & 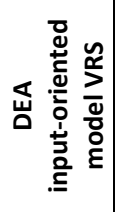 & 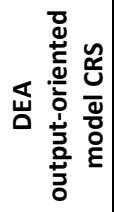 & 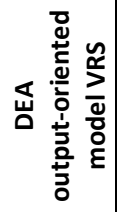 & 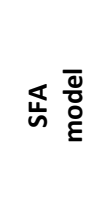 \\
\hline 01 & 0.38989 & 0.53920 & 0.38989 & 0.53920 & 0.23289 & 0.43280 & 0.53636 & 0.43280 & 0.48427 & 0.36067 & 0.40909 & 0.54525 & 0.40909 & 0.45467 & 0.99054 \\
\hline 02 & 0.86446 & 1.00000 & 0.86446 & 1.00000 & 0.72901 & 1.00000 & 1.00000 & 1.00000 & 1.00000 & 0.28185 & 1.00000 & 1.00000 & 1.00000 & 1.00000 & 0.99059 \\
\hline 03 & 0.96872 & 0.97667 & 0.96872 & 0.97667 & 0.75128 & 0.67583 & 0.71975 & 0.67583 & 0.69419 & 0.56510 & 0.63104 & 0.63812 & 104 & 0.69782 & 063 \\
\hline 04 & 1.00000 & 1.00000 & 1.00000 & 1.00000 & 0.69285 & 0.93104 & 0.96417 & 0.93104 & 0.96882 & 0.73909 & 0.97196 & 1.00000 & 0.97196 & 1.00000 & 0.99079 \\
\hline 05 & 0.96166 & 1.00000 & 0.96166 & 1.00000 & 0.96250 & 0.94756 & 0.94940 & 0.94756 & 0.95014 & 0.69421 & 0.62910 & 0.63248 & 0.62910 & 0.76786 & 0.99098 \\
\hline 06 & 1.00000 & 1.00000 & 1.00000 & 1.00000 & 0.67997 & 1.00000 & 1.00000 & 1.00000 & 1.00000 & 0.99979 & 0.90323 & 1.00000 & 323 & 1.00000 & 0.99054 \\
\hline 07 & 1.00000 & 1.00000 & 1.00000 & 1.00000 & 0.97302 & 0.78641 & 1.00000 & 0.78641 & 1.00000 & 0.80565 & 0.74536 & 0.80852 & 0.74536 & 0.93809 & 0.99072 \\
\hline 08 & 1.00000 & 1.00000 & 1.00000 & 1.00000 & 0.85339 & 1.00000 & 1.00000 & 1.00000 & 1.00000 & 0.98033 & 1.00000 & 1.00000 & 1.00000 & 1.00000 & 0.99103 \\
\hline 09 & 1.00000 & 1.00000 & 1.00000 & 1.00000 & 0.99988 & 0.93329 & 1.00000 & 0.93329 & 1.00000 & 0.95497 & 1.00000 & 1.00000 & 1.00000 & 1.00000 & 0.99085 \\
\hline 10 & 1.00000 & 1.00000 & 1.00000 & 1.00000 & 0.69117 & 1.00000 & 1.00000 & 1.00000 & 1.00000 & 0.99620 & 1.00000 & 1.00000 & 000 & 0000 & 0.5 \\
\hline 11 & 1.00000 & 1.00000 & 1.00000 & 1.00000 & 0.99991 & 1.00000 & 1.00000 & 1.00000 & 1.00000 & 0.86704 & 1.00000 & 1.00000 & 1.00000 & 1.00000 & 0.99073 \\
\hline 12 & 0.47847 & 0.92292 & 0.47847 & 0.92292 & 0.31688 & 0.70353 & 0.95998 & 0.70353 & 0.71383 & 0.44878 & 0.91100 & 0.98749 & 0.91100 & 0.97649 & 0.99045 \\
\hline 13 & 1.00000 & 1.00000 & 1.00000 & 1.00000 & 0.99985 & 1.00000 & 1.00000 & 1.00000 & 1.00000 & 0.86243 & 1.00000 & 1.00000 & 1.00000 & 1.00000 & \\
\hline 14 & 1.00000 & 1.00000 & 1.00000 & 1.00000 & 0.90306 & 1.00000 & 1.00000 & 1.00000 & 1.00000 & 0.73945 & 1.00000 & 1.00000 & 1.00000 & 1.00000 & 0.99095 \\
\hline 15 & 1.00000 & 1.00000 & 1.00000 & 1.00000 & 0.99850 & 1.00000 & 1.00000 & 1.00000 & 1.00000 & 0.99567 & 1.00000 & 1.00000 & 1.00000 & 1.00000 & 0.99088 \\
\hline 16 & 1.00000 & 1.00000 & 1.00000 & 1.00000 & 0.46733 & 1.00000 & 1.00000 & 1.00000 & 1.00000 & 0.44654 & 1.00000 & 1.00000 & 1.00000 & 1.00000 & 0.99063 \\
\hline 17 & 0.75908 & 0.76272 & 0.75908 & 0.76272 & 0.90119 & 0.73719 & 0.75976 & 0.73719 & 0.82889 & 0.86060 & 0.91547 & 0.96458 & 0.91547 & 0.97603 & 0.99087 \\
\hline 18 & 1.00000 & 1.00000 & 1.00000 & 1.00000 & 0.57364 & 1.00000 & 1.00000 & 1.00000 & 1.00000 & 0.85585 & 0.98858 & 0.98961 & 0.98858 & 0.99011 & 0.99089 \\
\hline 19 & 1.00000 & 1.00000 & 1.00000 & 1.00000 & 0.57395 & 0.76269 & 1.00000 & 0.76269 & 1.00000 & 0.32290 & 0.66818 & 1.00000 & 0.66818 & 1.00000 & 0.99039 \\
\hline 20 & 1.00000 & 1.00000 & 1.00000 & 1.00000 & 0.75042 & 1.00000 & 1.00000 & 1.00000 & 1.00000 & 0.99077 & 1.00000 & 1.00000 & 1.00000 & 1.00000 & 0.9 \\
\hline 21 & 0.68647 & 1.00000 & 0.68647 & 1.00000 & 0.30458 & 0.78474 & 1.00000 & 0.78474 & 1.00000 & 0.34473 & 0.83861 & 1.00000 & 0.83861 & 1.00000 & 0.99047 \\
\hline 22 & 1.00000 & 1.00000 & 1.00000 & 1.00000 & 0.61618 & 1.00000 & 1.00000 & 1.00000 & 1.00000 & 0.57296 & 0.87744 & 0.98600 & 0.87744 & 0.97008 & 0.99061 \\
\hline 23 & 1.00000 & 1.00000 & 1.00000 & 1.00000 & 0.59816 & 0.79201 & 0.91702 & 0.79201 & 0.80397 & 0.49686 & 0.48934 & 0.81916 & 0.48934 & 0.49720 & 0.99039 \\
\hline 24 & 1.00000 & 1.00000 & 1.00000 & 1.00000 & 0.50743 & 1.00000 & 1.00000 & 1.00000 & 1.00000 & 0.49792 & 1.00000 & 1.00000 & 1.00000 & 1.00000 & 0.99082 \\
\hline 25 & 1.00000 & 1.00000 & 1.00000 & 1.00000 & 0.63427 & 1.00000 & 1.00000 & 1.00000 & 1.00000 & 0.99630 & 1.00000 & 1.00000 & 1.00000 & 1.00000 & 0.99114 \\
\hline 26 & 1.00000 & 1.00000 & 1.00000 & 1.00000 & 0.82322 & 1.00000 & 1.00000 & 1.00000 & 1.00000 & 0.74878 & 0.82222 & 0.83872 & 0.82222 & 0.82655 & 0.99064 \\
\hline 27 & 0.73861 & 1.00000 & 0.73861 & 1.00000 & 0.63675 & 0.89101 & 1.00000 & 0.89101 & 1.00000 & 0.38899 & 1.00000 & 1.00000 & 1.00000 & 1.00000 & 0.99058 \\
\hline
\end{tabular}

Source: own elaboration. 
Table 6. SHVSs' efficiency in financial model_3 (output: income from sales)

\begin{tabular}{|c|c|c|c|c|c|c|c|c|c|c|c|c|c|c|c|}
\hline \multirow[b]{2}{*}{$\sum_{0}^{?}$} & \multicolumn{5}{|c|}{2009} & \multicolumn{5}{|c|}{2010} & \multicolumn{5}{|c|}{2011} \\
\hline & 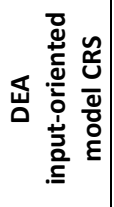 & 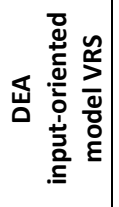 & 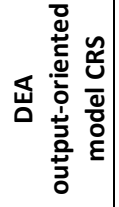 & 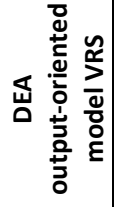 & 崩 & 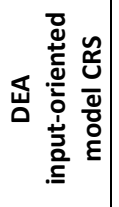 & 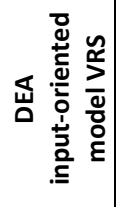 & 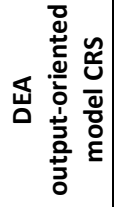 & 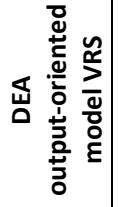 & 嵌 & 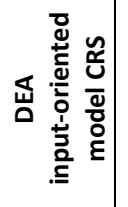 & 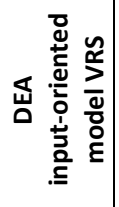 & 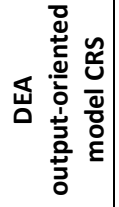 & 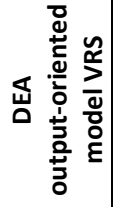 & 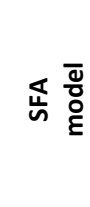 \\
\hline 01 & 0.05707 & 0.53920 & 0.05707 & 0.06030 & 0.02816 & 0.07589 & 0.51683 & 0.07589 & 0.08547 & 0.07388 & 0.09248 & 0.54525 & 0.09248 & 0.09655 & 0.04771 \\
\hline 02 & 1.00000 & 1.00000 & 1.00000 & 1.00000 & 0.40439 & 1.00000 & 1.00000 & 1.00000 & 1.00000 & 0.32581 & 1.00000 & 1.00000 & 1.00000 & 1.00000 & 0.53710 \\
\hline 03 & 1.00000 & 1.00000 & 1.00000 & 1.00000 & 0.99366 & 1.00000 & 1.00000 & 1.00000 & 1.00000 & 0.47155 & 1.00000 & 1.00000 & 1.00000 & 1.00000 & 0.60945 \\
\hline 04 & 0.22833 & 0.32708 & 0.22833 & 0.24582 & 0.28667 & 0.28637 & 0.52517 & 0.28637 & 0.30245 & 0.44010 & 0.32602 & 0.49216 & 0.32602 & 0.33461 & 0.37851 \\
\hline 05 & 1.00000 & 1.00000 & 1.00000 & 1.00000 & 0.86698 & 1.00000 & 1.00000 & 1.00000 & 1.00000 & 0.99040 & 0.93795 & 1.00000 & 0.93795 & 1.00000 & 0.96346 \\
\hline 06 & 0.21541 & 0.53768 & 0.21541 & 0.24133 & 0.13644 & 0.25080 & 0.63165 & 0.25080 & 0.32091 & 0.22812 & 0.21668 & 0.55685 & 0.21668 & 0.29848 & 0.10706 \\
\hline 07 & 0.91437 & 1.00000 & 0.91437 & 1.00000 & 0.75837 & 0.87513 & 1.00000 & 0.87513 & 1.00000 & 0.99974 & 0.89213 & 1.00000 & 0.89213 & 1.00000 & 0.90822 \\
\hline 08 & 1.00000 & 1.00000 & 1.00000 & 1.00000 & 0.93096 & 1.00000 & 1.00000 & 1.00000 & 1.00000 & 0.96944 & 1.00000 & 1.00000 & 1.00000 & 1.00000 & 0.98862 \\
\hline 09 & 1.00000 & 1.00000 & 1.00000 & 1.00000 & 0.70103 & 1.00000 & 1.00000 & 1.00000 & 1.00000 & 0.97487 & 1.00000 & 1.00000 & 1.00000 & 1.00000 & 0.85933 \\
\hline 10 & 1.00000 & 1.00000 & 1.00000 & 1.00000 & 0.84765 & 1.00000 & 1.00000 & 1.00000 & 1.00000 & 0.93213 & 1.00000 & 1.00000 & 1.00000 & 1.00000 & 0.98506 \\
\hline 11 & 1.00000 & 1.00000 & 1.00000 & 1.00000 & 0.99773 & 1.00000 & 1.00000 & 1.00000 & 1.00000 & 0.53973 & 1.00000 & 1.00000 & 1.00000 & 1.00000 & 0.82422 \\
\hline 12 & 0.14193 & 0.92292 & 0.14193 & 0.14655 & 0.05781 & 0.71117 & 0.95872 & 0.71117 & 0.77707 & 0.45147 & 0.88531 & 0.95589 & 0.88531 & 0.93123 & 0.31988 \\
\hline 13 & 1.00000 & 1.00000 & 1.00000 & 1.00000 & 0.72896 & 1.00000 & 1.00000 & 1.00000 & 1.00000 & 0.82436 & 1.00000 & 1.00000 & 1.00000 & 1.00000 & 0.99873 \\
\hline 14 & 1.00000 & 1.00000 & 1.00000 & 1.00000 & 0.54503 & 1.00000 & 1.00000 & 1.00000 & 1.00000 & 0.36524 & 1.00000 & 1.00000 & 1.00000 & 1.00000 & 0.51243 \\
\hline 15 & 1.00000 & 1.00000 & 1.00000 & 1.00000 & 0.79871 & 1.00000 & 1.00000 & 1.00000 & 1.00000 & 0.46978 & 1.00000 & 1.00000 & 1.00000 & 1.00000 & 0.94754 \\
\hline 16 & 1.00000 & 1.00000 & 1.00000 & 1.00000 & 0.51596 & 1.00000 & 1.00000 & 1.00000 & 1.00000 & 0.31504 & 1.00000 & 1.00000 & 1.00000 & 1.00000 & 0.38162 \\
\hline 17 & 0.22388 & 0.52357 & 0.22388 & 0.22994 & 0.16816 & 0.77260 & 0.98113 & 0.77260 & 0.98927 & 0.74538 & 0.94115 & 0.98197 & 0.94115 & 0.98772 & 0.52565 \\
\hline 18 & 1.00000 & 1.00000 & 1.00000 & 1.00000 & 0.75080 & 1.00000 & 1.00000 & 1.00000 & 1.00000 & 0.53012 & 1.00000 & 1.00000 & 1.00000 & 1.00000 & 0.87660 \\
\hline 19 & 1.00000 & 1.00000 & 1.00000 & 1.00000 & 0.29971 & 0.96265 & 1.00000 & 0.96265 & 1.00000 & 0.40313 & 0.94129 & 1.00000 & 0.94129 & 1.00000 & 0.78808 \\
\hline 20 & 1.00000 & 1.00000 & 1.00000 & 1.00000 & 0.99951 & 1.00000 & 1.00000 & 1.00000 & 1.00000 & 0.92374 & 1.00000 & 1.00000 & 1.00000 & 1.00000 & 0.99954 \\
\hline 21 & 0.95096 & 1.00000 & 0.95096 & 1.00000 & 0.41915 & 1.00000 & 1.00000 & 1.00000 & 1.00000 & 0.67337 & 1.00000 & 1.00000 & 1.00000 & 1.00000 & 0.36758 \\
\hline 22 & 1.00000 & 1.00000 & 1.00000 & 1.00000 & 0.57695 & 0.98105 & 0.98790 & 0.98105 & 0.98763 & 0.95741 & 0.96402 & 0.99606 & 0.96402 & 0.99275 & 0.37118 \\
\hline 23 & 1.00000 & 1.00000 & 1.00000 & 1.00000 & 0.36142 & 0.81978 & 0.91702 & 0.81978 & 0.82224 & 0.40734 & 1.00000 & 1.00000 & 1.00000 & 1.00000 & 0.48106 \\
\hline 24 & 1.00000 & 1.00000 & 1.00000 & 1.00000 & 0.37378 & 1.00000 & 1.00000 & 1.00000 & 1.00000 & 0.88792 & 1.00000 & 1.00000 & 1.00000 & 1.00000 & 0.99714 \\
\hline 25 & 0.24924 & 0.43207 & 0.24924 & 0.26776 & 0.22255 & 1.00000 & 1.00000 & 1.00000 & 1.00000 & 0.97794 & 1.00000 & 1.00000 & 1.00000 & 1.00000 & 0.86660 \\
\hline 26 & 1.00000 & 1.00000 & 1.00000 & 1.00000 & 0.51281 & 1.00000 & 1.00000 & 1.00000 & 1.00000 & 0.82430 & 1.00000 & 1.00000 & 1.00000 & 1.00000 & 0.56593 \\
\hline 27 & 1.00000 & 1.00000 & 1.00000 & 1.00000 & 0.33131 & 1.00000 & 1.00000 & 1.00000 & 1.00000 & 0.19220 & 1.00000 & 1.00000 & 1.00000 & 1.00000 & 0.66793 \\
\hline
\end{tabular}

Source: own elaboration. 
were recognized ( $37.04 \%$ of the analysed sample) with efficiency result over the average level.

In financial model_3 in 2009 the average efficiency ratio for CRS was $81.41 \%$, for the VRS input-oriented approach it was $89.94 \%$, for the VRS output-oriented approach it was $82.19 \%$, and for SFA it was $54.13 \%$. In 2009 in the CRS input-oriented approach 19 efficient higher education institutions were recorded ( $70.37 \%$ of the analysed sample), in the CRS output-oriented approach 21 efficient higher schools were identified $(77.78 \%$ of the analysed sample), in VRS 21 efficient DMUs were recognized ( $77.78 \%$ of the analysed sample). In the SFA approach 13 SHVSs were recorded ( $48.15 \%$ of the analysed sample) that reached the efficiency results over the average efficiency level. In 2010 the average efficiency ratio for CRS was $87.91 \%$, for the VRS input-oriented approach it was $94.51 \%$, for the VRS output-oriented approach it was $89.94 \%$, and for SFA it was $62.57 \%$. In 2010 in the CRS approach 18 efficient higher schools were recorded $(66.67 \%$ of the analysed sample), in the VRS approach 20 efficient DMUs were recorded (74.07\% of the analysed sample). In the case of the SFA method, 13 SHVSs were above average ( $48.15 \%$ of the analysed sample). In 2011, the average efficiency ratio in the financial model_3 for input- and output-oriented CRS was equal to $89.62 \%$, for input-oriented VRS it was $94.55 \%$, for outputoriented VRS it stood at $91.26 \%$, while for SFA it amounted to $66.21 \%$. In 2011, 18 efficient higher education institutions were recorded in the CRS approach $(66.67 \%$ of the analysed sample), while in the VRS approach there were 21 efficient higher education institutions ( $77.78 \%$ of the analysed sample). In the case of the SFA method, 16 SHVSs were above average ( $59.26 \%$ of the analysed sample).

\section{CONCLUSIONS}

When analysing the obtained results, it can be concluded that:

- SHVSs show high technical efficiency. For the didactic model_1 in the examined period, the average CRS efficiency oscillated from $91.61 \%$ to $95.47 \%$, for VRS from $95.96 \%$ to $98.86 \%$, while for SFA from $74.97 \%$ to $99.09 \%$. For the didactic model_2 in the examined period, the average CRS efficiency oscillated from $88.15 \%$ to $92.03 \%$, for VRS from $92.94 \%$ to $97.04 \%$, while for SFA from $69.68 \%$ to $71.00 \%$. In the financial model_3 in the examined period, the average CRS efficiency was ranging from $81.41 \%$ to $89.62 \%$, for VRS from $82.19 \%$ to $94.55 \%$, while for SFA from $54.13 \%$ to $66.21 \%$. Therefore, the lowest average efficiency of a higher education institution can be observed in the financial model, and in particular in the output-oriented VRS model (thus, an area that particularly requires efficiency improvement would entail activities related to the increase in income on sales of inefficient DMUs, while maintaining previously assumed input levels);

- in most cases the DEA and SFA methods provide concurrent results of analyses (i.e. high and low results obtained with the DEA method reflected high and low results calculated with the SFA method); 
- some DMUs examined with the DEA method achieve full efficiency once a variable return to scale (VRS) model is applied - the constant return to the scale model (VRS/CRS) did not show a given unit as efficient ${ }^{5}$;

- the majority of DMUs, found as inefficient in the analysis conducted with the DEA method with constant returns to scale (CRS) models, are found to be efficient in variable returns to scale (VRS) models, and demonstrate a relatively lower efficiency when calculated with the SFA method;

- moreover, substantial differences were found in the efficiency assessment with the DEA and SFA methods for DMU27. DEA mostly classifies this unit as efficient, whereas its efficiency calculated with the SFA method places it below average;

- DMU1 demonstrated the lowest efficiency in all models and in both methods;

- DMU20 demonstrated the highest efficiency in all models and in both methods.

The analysis results evidence high sensitivity of the models, which is a consequence of the selection of explained and explanatory variables.

It needs to be noted that in the case of higher education institutions it seems justified to apply models of variable returns to scale. It enables to identify the units that despite operating in a different scale (e.g. possessing fixed assets of relatively lower value, incurring lower remuneration costs or serving a smaller number of students) are fully efficient. In the case of a higher education institution, the size and scale of operations may have a significant impact on the efficiency of the conducted activity.

It was not the authors' intention to create a ranking of better and worse SHVSs, but to measure their efficiency, indicating areas for improvement.

This paper does not exhaust the subject and it provides a start to the authors' future deliberations.

The limitation for the presented study is a relatively short period of analysis which is caused by the limited accessibility to data published in governmental financial reports (Monitor B) that were obligatory only until the year 2011. However, the continuous and longitudinal study in this area will be required because of the demographic changes occurring in Poland in recent years (especially the decreasing number of students in Polish universities). Moreover, the comparative analysis of the efficiency of public and non-public Polish educational institutions is the promising area for future research.

\section{REFERENCES}

Abbott, M., \& Doucouliagos, C. (2003). The efficiency of Australian universities: a data envelopment analysis. Economics of Education Review, 22(1), 89-97.

Act on Higher Vocational Schools from 26 June 1997 (Dz. U. z 1997 r. Nr 96, poz. 590).

Aigner, D., Lovell, C.A.K., \& Schmidt, P. (1977). Formulation and Estimation of Stochastic Frontier Production Function Models. Journal of Econometrics, 6, 21-37.

Aoki, S., Inoue, K., \& Gejima, R. (2010). Data envelopment analysis for evaluating Japanese universities. Artif Life Robotics, 15, 165-170.

${ }^{5}$ The differences in technical efficiency calculated for the CRS and VRS models were marked in grey in Tables 4, 5 and 6. 
Athanassopoulos, A.D., \& Shale, E. (1997). Assessing the comparative efficiency of higher education institutions in the UK by the means of data envelopment analysis. Education Economics, 5(2), 117-134.

Avkiran, N.K. (2001). Investigating technical and scale efficiencies of Australian universities through data envelopment analysis. Socio-Economic Planning Sciences, 35(1), 57-80.

Banker, R.D., Charnes A., \& Cooper W.W. (1984). Some models for estimating technical and scale inefficiencies in data envelopment analysis. Management Science, 30(9), 1078-1092.

Bergantino, A.S., Capozza, C., \& Porcelli, F. (2012). Measuring Teaching Efficiency of the Italian University System: the Role of Market Structure. A two step DEA analysis at faculty level. Associazione Italiana di Scienze Regionali XXXIII Conferenza Scientifica Annuale Roma.

Charnes, A., Cooper, W.W., \& Rhodes, E. (1978). Measuring the efficiency of decision making units. European Journal of Operational Research, 429-444.

Cunha, M., \& Rocha, V. (2012). On the Efficiency of Public Higher Education Institutions in Portugal, An Exploratory Study. FEP Working Paper, no. 468, September 2012.

Ćwiąkała-Małys, A. (2010). Pomiar efektywności procesu kształcenia w publicznym szkolnictwie akademickim. Wrocław: Wyd. Uniwersytetu Wrocławskiego.

Farrell, M.J. (1957). The Measurement of Productive Efficiency. Journal of the Royal Statistical Society, Series A (General), 120(3), 253-290.

Figueiredo de Franca, J.M., Neiva de Figueriredo, J., \& Lapa, J. (2010). A DEA methodology to evaluate the impact of information asymmetry on the efficiency of not-for-profit organizations with an application to higher education in Brazil. Annals of Operations Research, 173, 39-56.

Johnes, J. (2006). Data envelopment analysis and its application to the measurement of efficiency in higher education. Economics of Education Review, 25(3), 273-288.

Kempkes, G., Pohl, C. (2010). The efficiency of German universities: some evidence from nonparametric and parametric methods. Applied Economics, 42, 2063-2079.

Koksla, G., \& Nalc, B. (2006). The relative efficiency of departments at a Turkish engineering college: A data envelopment analysis. Higher Education, 51, 173-189.

Lampe, W.H, \& Hilgers, D. (2015). Trajektories o efficiency measurement: A bibliometric analysis of DEA and SFA. European Journal of Operational Research, 240(1), 1-21.

Leitner, K.H., Prikoszovits, J., Schaffhauser-Linzatti, M., Stowasser, R., \& Wagners, K. (2007). The impact of size and specialisation on universities' department performance: A DEA analysis applied to Austrian universities. Higher Education, 53, 517-538.

MNiSW (2010). Szkolnictwo wyższe 2009. Dane podstawowe. Informator. MNiSW: Warszawa.

MNiSW (2011). Szkolnictwo wyższe 2010. Dane podstawowe. Informator. MNiSW: Warszawa.

MNiSW (2012). Szkolnictwo wyższe 2011. Dane podstawowe. Informator. MNiSW: Warszawa.

Monfared, M.A.S., Safi, M. (2013). Network DEA: an application to analysis of academic performance. Journal of Industrial Engineering International, 9(15).

Monitor B (2010-2012). http://www.monitorb.pl (retrieved on June 30, 2015).

Nazarko, J., Komuda, M., Kuźmicz, K., Szubzda, E., \& Urban, J. (2008). Metoda DEA w badaniu efektywności instytucji sektora publicznego na przykładzie szkół wyższych. Badania Operacyjne i Decyzje, 4, 89-105.

Nazarko, J., \& Saparauskas, J. (2014). Application of DEA method in efficiency evaluation of public higher education institutions. Technological and Economic Development of Economy, 20(1), 2544. http://dx.doi.org/10.3846/20294913.2014.837116 
Świtłyk, M., \& Mongiało, Z. (2013). Analiza współczynników efektywności uczelni publicznych. Prace Naukowe Uniwersytetu Ekonomicznego we Wrocławiu, 307, 420-430.

Świtłyk, M., \& Pasewicz, W. (2010). Zastosowanie DEA do oceny efektywności technicznej działalności dydaktycznej uczelni publicznych w 2005 roku. Zeszyty Naukowe Zachodniopomorskiego Uniwersytetu Technologicznego w Szczecinie, 87-98.

Szymańska, E. (2010). Efektywność przedsiębiorstw - definiowanie i pomiar. Rocznik Nauk Rolniczych, 97(2).

Warning, S. (2004). Performance Differences In German Higher Education: Empirical Analysis of Strategic Groups. Review of Industrial Organization 24(4), 393-408.

Wolszczak-Derlacz, J. (2013). Efektywność naukowa, dydaktyczna i wdrożeniowa publicznych szkół wyższych w Polsce - analiza nieparametryczna. Gdańśk: Wyd. Politechniki Gdańskiej. 


\section{Authors}

The contribution of co-authors is 70\% - L. Rządziński and 30\% - A. Sworowska. L. Rządziński prepared the literature review, collected data, prepared part of statistical calculations (SFA method) and elaborated conclusions. A. Sworowska prepared part of statistical calculations (DEA), edited and reviewed the paper as well as elaborated conclusions.

\section{Lesław Rządziński}

Bachelor of Science in Pedagogy (University of Szczecin, Poland), Master of Science in Economics (Agricultural University of Szczecin, Poland); PhD student of Management Sciences (University of Szczecin, Poland). Since 2013 an assistant professor at West Pomeranian University of Technology in Szczecin (Poland).

Correspondence to: mgr Lesław Rządziński, West Pomeranian University of Technology in Szczecin, Faculty of Economics, ul. Janickiego 31, 71-270 Szczecin, Poland, e-mail: leslaw.rzadzinski@zut.edu.pl

\section{Anna Sworowska}

PhD in Management Sciences in 2013 by the Silesian University of Technology (Poland). Since 2013 an adjunct professor at West Pomeranian University of Technology in Szczecin (Poland).

Correspondence to: Dr Anna Sworowska, West Pomeranian University of Technology in Szczecin, Faculty of Economics, ul. Janickiego 31, 71-270 Szczecin, Poland, e-mail: anna.sworowska@zut.edu.pl

\section{Copyright and License}

This article is published under the terms of the Creative Commons Attribution - NonCommercial - NoDerivs (CC BY-NC-ND 3.0) License http://creativecommons.org/licenses/by-nc-nd/3.0/ 